\title{
SELENIUM SUPPLY AND THYROID CONDITION IN GRAVES' DISEASE IN THE REGION OF IODINE DEFICIENCY*
}

\author{
Kravchenko V. I. ${ }^{1}$, Grossman A. B. ${ }^{2}$, Rakov O. V. ${ }^{1}$, \\ Kovzun O. I. ${ }^{1}$, Pankiv V. I. ${ }^{3}$, Simurov O. V. ${ }^{1}$ \\ ${ }^{1}$ V. Komisarenko State Institute of Endocrinology and Metabolism National Academy \\ of Medical Sciences of Ukraine, Kyiv, Ukraine; \\ ${ }^{2}$ Green-Templeton College at the University of Oxford, UK; \\ ${ }^{3}$ Ukrainian Research and Practical Center of Endocrine Surgery, \\ Transplantation of Endocrine Organs and Tissues Ministry of Health of Ukraine, Kyiv, Ukraine \\ endocr@i.ua
}

Selenium is a necessary element in maintaining human health. Selenium is a micronutrient embedded in several proteins. The thyroid is the organ with the highest amount of selenium per gram of tissue. Selenium levels in the body depend on the characteristics of the population and its diet, geographic area, and soil composition [1]. In the thyroid, selenium is required for the antioxidant function and for the metabolism of thyroid hormones. This element is part of the enzyme glutathione peroxidase, which is common in the body and is found in almost all cells, where it protects polyunsaturated membrane lipids from oxidative degradation. In addition, glutathione peroxidase encodes 25 genes for the synthesis of 30 selenoproteins due to alternative splicing [2]. Selenium is also part of selenoproteins, which have a wide range of polytropic effects of antioxidant, antiinflammatory and antitumor effects. Selenium deficiency leads to degeneration of many organs and tissues as a result of reduced expression of selenoproteins and, as a consequence, disruption of the biological processes in which they participate. Existing observations suggest that low levels of selenium in the human body are associated with an increased risk of mortality, decreased immunity, cardiovascular disease, cancer, infertility in men and women, a number of psycho-emotional disorders, pathology of internal organs and endocrine system [3-5]. Among other organs, the highest content of selenium is observed in the thyroid. In this gland, the element plays an important

* The work was carried out in accordance with the scientific theme of the department of Epidemiology of Endocrine Diseases of V. Komisarenko State Institute of Endocrinology and Metabolism National Academy of Medical Sciences of Ukraine «Develop and investigate the effectiveness of new means of prevention of diseases of the endocrine system in order to implement them in clinical practice» (State registration number: 0120U100646).

Institution, which financed the research: National Academy of Medical Sciences of Ukraine.

The authors assume responsibility for the published work.

The authors guarantee absence of competing interests and their own financial interest when carrying out the research and writing the article.

The manuscript was received by the editorial staff 26.10.2020. 
role in ensuring the synthesis and metabolism of thyroid hormones, its deficiency may be one of the causes of thyroid disease [6, 7]. Graves' disease attracts a lot of attention among specialists among these diseases. Graves' disease is an autoimmune disease of the thyroid and is caused by an increase in the titer of receptor antibodies, which cause stimulation of thyroid hormone receptors to thyroid-stimulating hormone (TSH) and due to activation of cyclic adenosine monophosphate. Antibodies to TSH receptor (rTSH Ab) are a clinical and laboratory marker of Graves' disease and are studied in the differential diagnosis of hyperthyroidism. The presence of rTSH Ab is not characteristic of other causes of hyperthyroidism, such as toxic nodular goiter, granulomatous thyroiditis or the introduction of exogenous levothyroxine. Stimulating rTSH Ab are found in $85-100 \%$ of patients with Graves' disease and used as a diagnostic criterion. The concen- tration of rTSH Ab reflects the activity of the disease and is associated with the severity of ophthalmopathy. In Graves' disease the basal metabolic status of patients accelerates, which leads to a significant increase in the proportion of free radicals and reactive oxygen species $[8,9]$. Studies of the level of an important antioxidant element selenium in the blood in Graves' disease have shown a significant decrease [10]. However, in some studies, the discovered fact was not confirmed [8]. Other studies have shown the dependence of selenium levels in Graves' disease on iodine supply [11]. With iodine deficiency, its content in the body is often accompanied by a lack of selenium.

The aim of the study was to investigate the level of selenium in the serum, the median urinary iodine excretion, relationship between selenium and ioduria levels in patients with Graves' disease.

\section{MATERIALS AND METHODS}

141 residents of Kyiv City and Kyiv region were examined: 37 of them without thyroid pathology (7 men and 30 women) were the control group, and 104 patients who first applied to the consultative outpatient clinic of the V. Komisarenko Institute of Endocrinology and Metabolism in the period of 2018-2019. All patients were with newly diagnosed Graves' disease of moderate severity. The average age of patients was $43.25 \pm 1.18$ years (17-65), among them were $22.4 \%$ men and $77.6 \%$ women. Exclusion criteria were: age of patients younger 17 years and over 65 years; persons with severe disorders of internal organs, pregnant women; patients who have used antithyroid drugs due to previously diagnosed thyrotoxicosis; patients with nodular goiters; patients with orbitopathy. The diagnosis of Graves' disease was established on the basis of patient complaints, anamnesis data, typical clinical picture and results of laboratory examination of thyroid and immunological status.

Prior to treatment, all patients underwent a complete biochemical blood test, a general urine test to rule out acute infectious diseases, severe renal and hepatic impairment. Control of adverse effects of thiamazole treatment was carried out by clinical analysis of blood. The thyroid functional state was examined for the content of hormones (thyroid-stimulating hormone - TSH, free thyroxine - $\mathrm{fT}_{4}$ ) by radioimmunoassay using standard kits from the company «Immunotech» (Czech Republic) designed for the quantitative detection of these hormones. Reference values according to the set of reagents used for fT4 - 11.0-23.0 pmol/l, TSH 0.17-4.0 $\mathrm{mIU} / \mathrm{ml}$. Determination of receptor TSH Antibodies (rTSH Ab) was performed using an automatic immunochemiluminescent system IMMULITE 2000, which uses recombinant human TSH receptors. These indicators are markers of reliable diagnosis of Graves' disease (sensitivity 98.3\%, specificity 99.7\%). Normal values of rTSH Ab were considered to be not exceeding $0.7 \mathrm{mIU} / \mathrm{l}$. The levels of $\mathrm{TSH}, \mathrm{fT}_{4}, \mathrm{fT}_{3}, \mathrm{rTSH} \mathrm{Ab}$ and serum selenium were determined in patients before treatment, 3 and 6 months after starting treatment with thiamazole.

Studies of serum selenium were performed by fluorometric method after acid mineralization of serum samples. The determination is based on the sensitive and selective reaction of the interaction of selenic acid with 2,3-diaminonaphthene, which results in the formation of 4,5-benzopiazoselenol, which has fluorescence. 
The concentration of selenium was determined by spectrofluorometry at an excitation wavelength of $366 \mathrm{~nm}$ and fluorescence of $520 \mathrm{~nm}$. The lower and upper reference levels of selenium content in the serum of selenium were 0.060-0.12 mg/l [12]. Determination of iodine concentartion in urine was performed by the cerium-arsenite method Sandell-Kolthoff in the Dunn modification [13]. The results of the study were interpreted according to WHO criteria [14]. Normal iodine values are 100 to 200 micrograms per liter. Studies of ioduria were investigated under constant external quality control at the CDC Center, Atlanta (USA).

Thyroid ultrasound examination was performed with the device "Toshiba" SSA-580A and "Ultima» RA GRIS.941217.01343 before treatment and 3 and 6 months after treatment.
Statistical data processing was performed in accordance with the requirements of evidence-based medicine and biostatistics, using the approaches of modern non-infectious epidemiology. The statistical package used the software package SPSS 16.0 and MedStat. Mann-Whitney criteria were used for odd comparisons, and Wilcoxon criteria were used for related samples, and $\mathrm{p}<0.05$ values were considered to be significantly significant.

Ethical approval for the study was obtained from the V. Komisarenko Institute of Endocrinology and Metabolism Ethics Committee (protocol № 7; 29.11.2018). All participants were briefed about the study and gave informed written consent to participate.

\section{RESULTS AND THEIR DISCUSSION}

Most patients in both goups (control group and Graves' disease group) had selenium deficiency. The analysis of the results showed an incorrect distribution, both for selenium and for other indicators, so for their statistical analysis the median indicators and 25 and 75 percentiles were used. In the control group, the median selenium content was $56.5 \mathrm{mg} / \mathrm{l}$ with a permissible serum selenium of $60-120 \mathrm{mg} / \mathrm{l}$. Only $30 \%$ of the results corresponded to normal values.

In $51.7 \%$ of the subjects observed a reduced level of selenium less than $60 \mathrm{mg} / \mathrm{l}$, and in $20.7 \%$ of them the level of the selenium in the blood was significantly reduced — less than $20 \mathrm{mg} / \mathrm{l}$.

In patients with Graves' disease the selenium level was significantly decreased, it was almost twice lower than in the control group $(29.35 \mathrm{mg} / \mathrm{l} ; \mathrm{p}<0,001)$. Within normal values it was only $26.6 \%$. Decreased serum selenium was observed in $73.4 \%$ of patients with Graves' disease, of which $50 \%$ were less than $20 \mathrm{Mg} / \mathrm{l}$.

As expected, there was a significant increase in the production of thyroid hormones in Graves' disease compared with controls. The level of $\mathrm{fT}_{4}$ was increased almost twice. Accordingly, there was a significant inhibition of TSH level (Fig. 1) 0.05 [0.02-0.105], in the control group $1.24[0.76-2.145] \mathrm{mIU} / \mathrm{ml}$. The active pathological process in the thyroid gland and immunological changes were indicated by an almost 100-fold increased titer of rTSH Ab.

An important factor in the prevalence of thyroid disease is iodine supply.

Studies have shown that the subjects of the control group were in the zone of iodine deficiency, however, if for the control group the median of ioduria corresponded to a moderate degree of iodine deficiency, in the group with Graves' disease there was a sufficient iodine supply.

It is known that women suffer more from thyroid diseases than men. In our studies among 104 patients, women were $77.6 \%$, a significant difference in all studied indicators depending on gender was not observed. This indicated the identity of the development of Graves' disease in patients of both sexes and allowed to combine the data of men and women for further analysis.

An important factor for the course of various diseases is the age of patients. Among those examined were patients aged 17 to 65 years. Subjects with Graves' disease we divided into age groups as shown in table 1 . Analysis of the results showed that in the age group 51 years and older compared to other groups was increased levels of $\mathrm{fT}_{3}$. Significantly higher thyroid volumes were found in subjects aged 41-50 years and older than 51 years. In the same age groups, the level of selenium in the blood was markedly reduced (Table 1). 


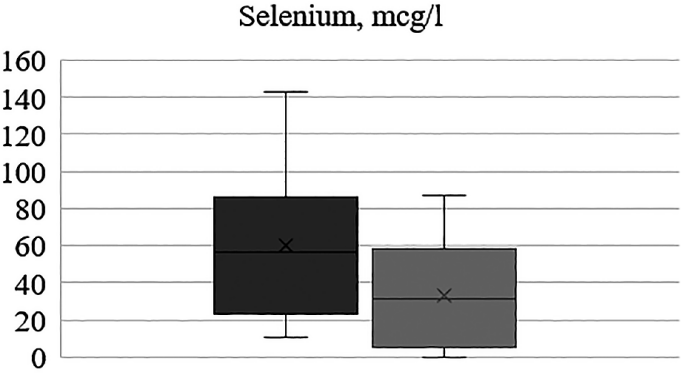

- Control group $\square$ Graves' disease

$\mathrm{TSH}, \mathrm{mIU} / \mathrm{l}$

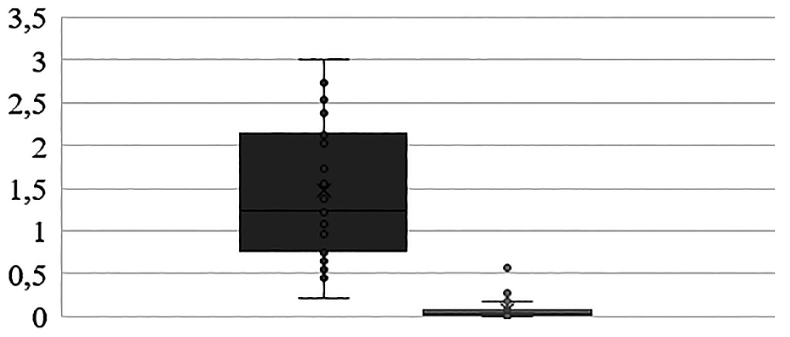

घ Control group $\square$ Graves' disease

$\mathrm{fT}_{4} \mathrm{pmol} / \mathrm{l}$

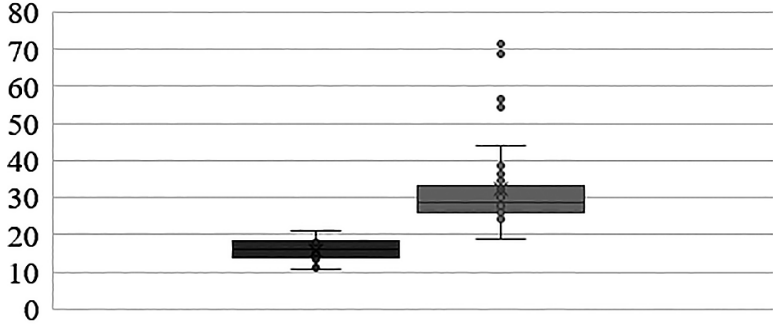

- Control group $\square$ Graves' disease
Ioduria, $\mathrm{mcg} / \mathrm{l}$

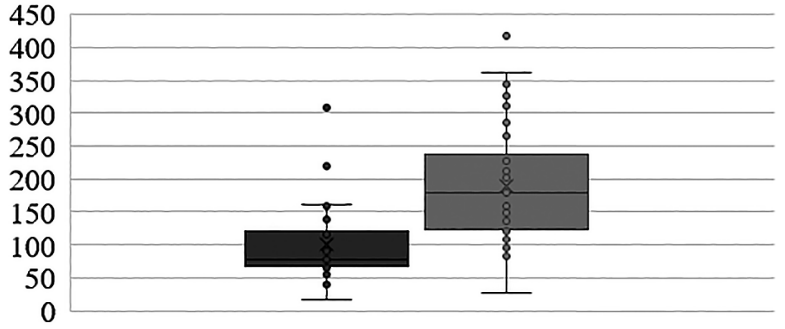

$\square$ Control group $\square$ Graves' disease

$\mathrm{fT}_{3, \mathrm{pmol} / \mathrm{l}}$

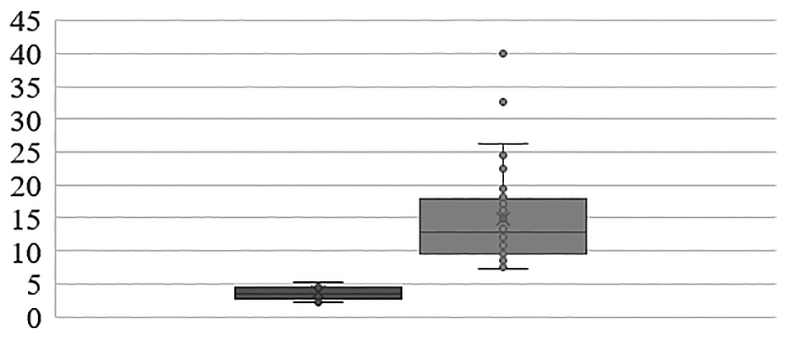

$\square$ Control group $\square$ Graves' disease

rTSH Ab, IU/l

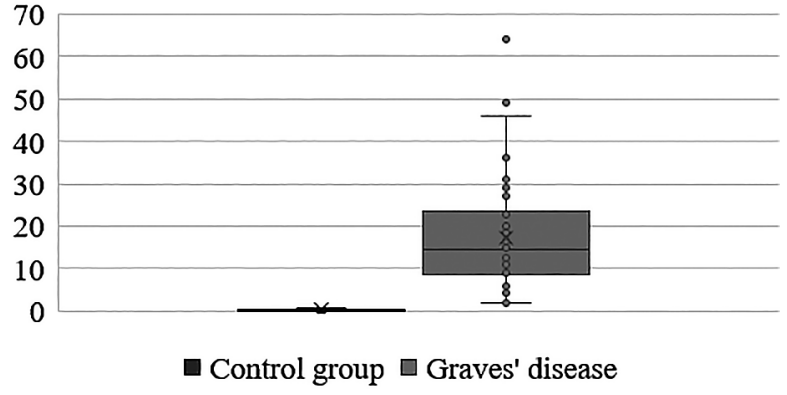

Thyroid volume, $\mathrm{cm}^{3}$



Fig. 1. Indicators of selenium levels, rTSH Ab titer in the blood and thyroid status in the control group and in patients with Graves' disease.

Treatment of patients with Graves' disease had a positive effect. One month after the start of treatment there was a significant decrease in $\mathrm{fT}_{4}$ and $\mathrm{fT}_{3}$ levels to normal values and TSH in the serum (Table 2). The same positive changes were observed after 6 months of treatment. Significant positive changes were registered in the level of rTSH Ab in the blood, and with the extension of treatment to 6 months, this positive trend persisted $(p<0.005)$. When compared with the indicator in the control group, the titer of rTSH Ab still remained elevated $(p<0.001)$.

A slight increase in serum selenium levels and a significant decrease of thyroid volume also indicated an improvement of thyroid status. 
Indicators of thyroid status and selenium levels, rTSH Ab in patients with Graves' disease of different ages before treatment

\begin{tabular}{|c|c|c|c|c|}
\hline \multirow{2}{*}{ Indexes } & $<30$ years & $31-40$ years & years & $>51$ years \\
\hline & $\mathrm{n}=17$ & $n=27$ & $\mathrm{n}=32$ & $n=28$ \\
\hline $\mathrm{Se}, \mathrm{mcg} / \mathrm{l}$ & $50.9[38.9-72.0]$ & 34.4 [17.4-63.5] & $28.3[9.7-57.8]^{*}$ & $7.0[2.1-39.1]^{* \#}$ \\
\hline $\mathrm{f}^{\prime} \mathrm{T}_{4} \mathrm{pmol} / \mathrm{l}$ & $\begin{array}{c}29.4 \\
{[26.3-34.36]}\end{array}$ & $\begin{array}{c}30.06 \\
{[27.9-32.61]}\end{array}$ & $\begin{array}{c}28.7 \\
{[25.7-36.05]}\end{array}$ & $\begin{array}{c}31.7 \\
{[27.945-36.65]}\end{array}$ \\
\hline $\mathrm{fT}_{3}, \mathrm{pmol} / \mathrm{l}$ & $\begin{array}{c}11.1 \\
{[9.11-14.45]}\end{array}$ & $\begin{array}{c}13.4 \\
{[11.57-18.4]^{*}}\end{array}$ & $\begin{array}{c}11.55 \\
{[10.045-17.65]}\end{array}$ & $\begin{array}{c}15.22 \\
{[11.155-20.5]^{*}}\end{array}$ \\
\hline $\mathrm{TSH}, \mathrm{mIU} / \mathrm{ml}$ & $\begin{array}{c}0.02 \\
{[0.01-0.07]}\end{array}$ & $\begin{array}{c}0.02 \\
{[0.0075-0.05]}\end{array}$ & $\begin{array}{c}0.02 \\
{[0.002-0.05]}\end{array}$ & $\begin{array}{c}0.023 \\
{[0.007-0.0705]}\end{array}$ \\
\hline rTSH-Ab, IU/l & $9.26[7.22-19.6]$ & $14.8[8.35-21.1]$ & $15.05[6.77-18.6]$ & $15.15[10.45-29.2]$ \\
\hline Thyroid volume, $\mathrm{cm}^{3}$ & $\begin{array}{c}19.3 \\
{[15.96-29.06]}\end{array}$ & $\begin{array}{c}23.24 \\
{[19.09-46.14]}\end{array}$ & $\begin{array}{c}31.4 \\
{[25.61-42.82]^{*}}\end{array}$ & $\begin{array}{c}31.935 \\
{[26.46-52.78]^{*}}\end{array}$ \\
\hline Ioduria, mcg/l & $\begin{array}{c}165.0 \\
{[116.5-218]}\end{array}$ & $\begin{array}{c}179.0 \\
{[149.4-268]}\end{array}$ & $\begin{array}{c}184.5 \\
{[124.75-266.0]}\end{array}$ & $\begin{array}{c}163.05 \\
{[114.55-204.9]}\end{array}$ \\
\hline
\end{tabular}

Data are presented as median IU and quartiles [Q1-Q3].

* $\mathrm{p}<0.05$ - in comparison with the group < 30 years;

\# $\mathrm{p}<0.05$ - compared with the group of 31-40 years.

Table 2

The effect of Graves' disease treatment on blood selenium levels and thyroid status

\begin{tabular}{c|c|c|c}
\hline Indexes & Before treatment & After 3 months & After 6 months \\
\hline $\mathrm{Se}, \mathrm{mcg} / \mathrm{l}$ & $23.4[2.65-60.13]$ & $27[7.58-62.33]^{*}$ & $24,5[8.48-57.78]^{* \#}$ \\
\hline $\mathrm{fT}_{4}, \mathrm{pmol} / \mathrm{l}$ & $28.58[26.29-33.97]$ & $14.41[12.34-16.98]^{*}$ & $14.84[13.9-16.38]^{* *}$ \\
\hline $\mathrm{fT}_{3}, \mathrm{pmol} / \mathrm{l}$ & $13.52[9.74-17.1]$ & $3.12[2.77-3.65]^{*}$ & $3.03[2.75-3.46]^{*}$ \\
\hline $\mathrm{TSH}, \mathrm{mIU} / \mathrm{ml}$ & $0.05[0.02-0.11]$ & $0.94[0.65-1.22]^{*}$ & $1.78[1.49-2.13]^{* \#}$ \\
\hline $\mathrm{rTSH} \mathrm{Ab}, \mathrm{IO} / \mathrm{l}$ & $15.4[10.38-20.33]$ & $5.6[3.66-8.68]^{*}$ & $1.18[0.52-2.58]^{* \#}$ \\
\hline Thyroid volume, $\mathrm{cm}^{3}$ & $25.96[14.55-35.73]$ & $23.13[12.69-38.45]^{*}$ & $22.85[12.37-36.46]^{* \#}$ \\
\hline Ioduria, $\mathrm{mcg} / 1$ & $173.05[121.5-264.75]$ & $122.45[100-189.9]^{* *}$ & - \\
\hline
\end{tabular}

Data are presented as median IU and quartiles [Q1-Q3].

* $\mathrm{p}<0.05$ - compared with the group before treatment;

\# $\mathrm{p}<0.05$ - compared between groups after 3 and 6 months.

However, most patients after 3 and 6 months of treatment were in significant selenium deficiency, which clearly indicates the need for its correction.

The presence of significant changes in thyroid function, immune status of patients and selenium levels in the blood indicated the need for correlation analysis between these indicators. Accordingly, the analysis was also performed in the control group. In the control group there was a significant correlation between the level of TSH and the level of $\mathrm{fT}_{3}$ and $\mathrm{fT}_{4}$. It is noteworthy that in the group of patients with Graves' disease registered a re- lationship between selenium and ioduria $(p<0.05)$, there is a correlation between the titer of rTSH Ab and thyroid function (Table 3).

The same correlations are registered during the treatment of patients with Graves' disease. Taking into account the data of correlation analysis and the identified relationships between the studied indicators, we calculated the risks of changes in antibody titer depending on the level of selenium and other studied factors.

Analysis data showed that increasing the level of selenium in the blood helps to reduce the titer of rTSH Ab. Positive effect shows the normalization of inhibited low levels of TSH. 
High levels of $\mathrm{fT}_{4}, \mathrm{fT}_{3}$, increased thyroid volume and high levels of ioduria increase the risk of antibodies to the thyroid-stimulating hormone receptor.

Thus, in patients with Graves' disease there is a reduced level of selenium in the blood, which correlates with significantly increased titer of rTSH Ab. We found that changes in antibody titers in male and female patients did not differ. There were no differences between these indicators depending on the age of patients. After 3, 6 months of Graves' disease treatment the level of selenium in the serum increases, but remains reduced compared to control group. We confirm that the decrease in serum selenium levels is due to disease, thyroid dysfunction and pro-inflammatory processes [15]. The importance of thyroid function in the regulation of selenium levels is indicated by existing publications [16, 17]. Treatment due to improved selenium metabolism in the body and thyroid gland leads to significant improvement in the synthesis and metabolism of thyroid hormones and increase in its concentration in the serum and a significant improvement of immunological parameters. The obtained data indicate the need to study the content of selenium in the blood of patients with thyroid pathology, followed by a decision on the need to use dietary supplements containing selenium.

\section{CONCLUSIONS}

In patients with Graves' disease the selenium level was significantly decreased, it was almost twice lower than in the control group $(29.35 \mathrm{mg} / \mathrm{l} ; \mathrm{p}<0,001)$. Within normal values Correlation between selenium levels and thyroid status
in control and in patients with Graves' disease

Table 3

\begin{tabular}{|c|c|c|c|c|c|}
\hline \multicolumn{3}{|c|}{ Control group } & \multicolumn{3}{|c|}{$\begin{array}{c}\text { Patients with Graves'disease } \\
\text { before treatment }\end{array}$} \\
\hline Indexes & $\begin{array}{l}\text { Spearman } \\
\text { coefficient }\end{array}$ & $\mathbf{p}$ & Indexes & $\begin{array}{l}\text { Spearman } \\
\text { coefficient }\end{array}$ & $\mathbf{p}$ \\
\hline Age - rTSH Ab & -0.183 & 0.341 & Age - rTSH Ab & -0.209 & 0.268 \\
\hline $\begin{array}{l}\text { Selenium - } \\
\text { Thyroid volume }\end{array}$ & -0.293 & 0.123 & $\begin{array}{l}\text { Selenium - } \\
\text { Thyroid volume }\end{array}$ & 0.028 & 0.884 \\
\hline Selenium - Ioduria & 0.236 & 0.218 & Selenium - Ioduria & -0.368 & 0.046 \\
\hline $\begin{array}{l}\text { Selenium - } \\
\text { rTSH Ab }\end{array}$ & 0.170 & 0.378 & $\begin{array}{l}\text { Selenium - } \\
\text { rTSH Ab }\end{array}$ & 0.366 & 0.047 \\
\hline Selenium - TSH & -0.079 & 0.684 & Selenium - TSH & -0.046 & 0.808 \\
\hline $\mathrm{TSH}-\mathrm{fT}_{4}$ & -0.463 & 0.012 & $\mathrm{TSH}-\mathrm{fT}_{4}$ & -0.476 & 0.008 \\
\hline $\mathrm{TSH}-\mathrm{fT}_{3}$ & 0.455 & 0.013 & $\mathrm{TSH}-\mathrm{fT}_{3}$ & 0.546 & 0.002 \\
\hline $\mathrm{fT}_{4}-\mathrm{fT}_{3}$ & -0.429 & 0.02 & $\mathrm{fT}_{4}-\mathrm{fT}_{3}$ & 0.546 & 0.002 \\
\hline Selenium $-\mathrm{fT}_{4}$ & -0.035 & 0.858 & Selenium $-\mathrm{fT}_{4}$ & 0.211 & 0.262 \\
\hline
\end{tabular}

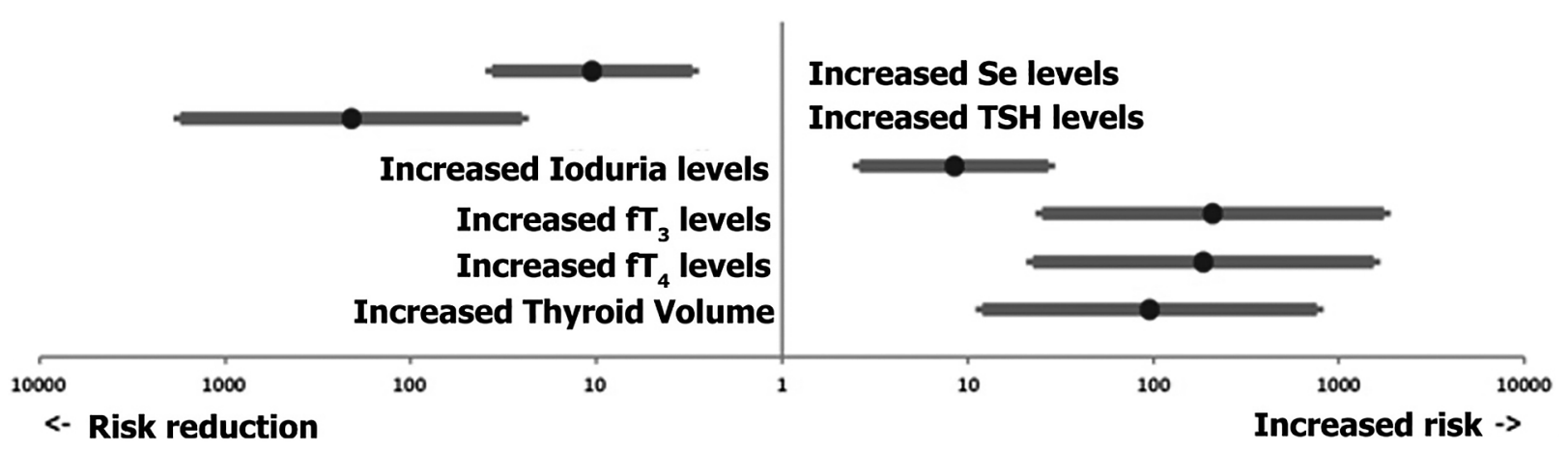

Figure 2. Risk of increased rTSH Ab from selenium levels and thyroid status. 
it was only $26.6 \%$. Decreased serum selenium was observed in $73.4 \%$ of patients with Graves' disease, of which $50 \%$ were less than $20 \mathrm{mg} / \mathrm{l}$.

In the control group there was a significant correlation between the level of TSH and the level of $\mathrm{fT}_{3}$ and $\mathrm{fT}_{4}$. In the group of patients with Graves' disease registered a relationship between selenium and ioduria $(p<0.05)$, correlation between the titer of rTSH Ab and thyroid function.

Analysis data showed that increasing the level of selenium in the blood helps to reduce the titer of rTSH Ab.

\title{
REFERENCES
}

1. Ventura M, Melo M, Carrilho F. Int J Endocrinol 2017; 2017: 1297658. doi: 10.1155/2017/1297658.

2. Duntas LH, Benvenga S. Endocrine 2015; 48(3): 756775. doi: 10.1007/s12020-014-0477-6.

3. Rayman MP. Lancet 2012; 379(9822): 1256-1268. doi: 10.1016/S0140-6736(11)61452-9

4. Schomburg L. Nat Rev Endocrinol 2012; 8(3): 160-171. doi: 10.1038/nrendo.2011.174.

5. Thiry C, Ruttens A, Pussemier L, Schneider YJ. Brit J Nutr 2013; 109(12): 2126-2134. doi: 10.1017/S000711451 2004412.

6. Park K, Rimm E, Siscovick D, et al. Nutr Res Pract 2011; 5(4): 357-364. doi: 10.4162/nrp.2011.5.4.357.

7. Kipp AP, Strohm D, Brigelius-Flohe R, et al. J Trace Elem Med Biol 2015; 32: 195-199. doi: 10.1016/j.jtemb. 2015.07.005.

8. Zheng H, Wei J, Wang L, et al. Evid Based Complement Alternat Med 2018; 2018: 3763565. doi: 10.1155/2018/ 3763565 .

9. Wang L, Wang B, Chen SR, et al. Horm Metab Res 2016; 48(9): 559-564. doi: 10.1055/s-0042-110491.
10. Sadaka A, Nguyen K, Malik A, et al. Neuroophthalmology 2019; 43(5): 291-294. doi: 10.1080/01658107.2019. 1566382 .

11. Dehina N, Hofmann PJ, Behrends T, et al. Eur Thyroid J 2016; 5(1): 57-64. doi: 10.1159/000442440.

12. Kipp AP, Strohm D, Brigelius-Flohé R, et al. J Trace Elem Med Biol 2015; 32: 195-199. doi: 10.1016/j.jtemb. 2015.07.005.

13. Xiu L, Zhong G, Ma X. PLoS One 2017; 12(3): e0174095. doi: 10.1371/journal.pone.0174095.

14. Assessment of iodine deficiency disorders and monitoring their elimination: a guide for programme managers. 3rd ed, Geneva, 2007: $97 \mathrm{p}$.

15. Wertenbruch T, Willenberg HS, Sagert C, et al. Med Chem 2007; 3(3): 281-284. doi: 10.2174/157340607780 620662 .

16. Goncharova OA. Probl Endocrin Pathology 2016; 1: 63-70.

17. Khong JJ, Goldstein RF, Sanders KM, et al. Clin Endocrinol 2014; 80(6): 905-910. doi: 10.1111/cen.12392.

\author{
SELENIUM SUPPLY AND THYROID CONDITION \\ IN GRAVES' DISEASE IN THE REGION OF IODINE DEFICIENCY \\ Kravchenko V. I. ${ }^{1}$, Grossman A. B. ${ }^{2}$, Rakov O. V. ${ }^{1}$, \\ Kovzun O. I. ${ }^{1}$, Pankiv V. I. ${ }^{3}$, Simurov O. V. ${ }^{1}$ \\ ${ }^{1}$ V. Komisarenko State Institute of Endocrinology and Metabolism National Academy \\ of Medical Sciences of Ukraine, Kyiv, Ukraine; \\ ${ }^{2}$ Green-Templeton College at the University of Oxford, UK; \\ ${ }^{3}$ Ukrainian Research and Practical Center of Endocrine Surgery, \\ Transplantation of Endocrine Organs and Tissues Ministry of Health of Ukraine, Kyiv, Ukraine \\ endocr@i.ua
}

The aim of the study was to investigate the level of selenium in the serum, the median urinary iodine excretion, relationship between selenium and ioduria levels in patients with Graves' disease. 141 residents of Kyiv and Kyiv region were examined, 37 of them without thyroid pathology (control group) aged $39.7 \pm 2.7$ years, and 104 with Graves' disease (experimental group), aged $43.25 \pm 1.18$ years. The level of selenium in the serum of patients was significantly reduced compared to control. Its median was 29.35 and 1-3 quartiles [6.85-58.77] $\mathrm{mg} / \mathrm{l}$, respectively. With age, selenium deficiency worsened. In the study of thyroid status, the group of patients with Graves' disease differed from the control of elevated thyroid hormone levels, decreased TSH levels, increased thyroid volume. There was a significant increase in the level of antibodies to TSH receptors more than 100 times. Dependence of these indicators on sex and age of patients was not observed. The median urinary iodine excretion in the experimental group was significantly different $(p<0.05)$, its value in the control group was $78.9 \mathrm{mg} / \mathrm{l}$, which indicated the presence of mild iodine deficiency, in the experimental group it was $177.05 \mathrm{mg} / \mathrm{l}$. After 3 and after 6 months after methimazole treatment, the level of selenium in the blood 
increased, but remained reduced compared to control. There was a complete normalization of thyroid hormones levels and TSH. In the group of patients, a relationship between selenium and ioduria levels was registered $(\mathrm{p}<0.05)$, there was a correlation between the titer of antibodies to the TSH receptor, and as in the control, a correlation between thyroid function $(p<0.05)$. Calculation of the risks of changes in antibody titers depending on the level of selenium and other studied factors showed that increasing the level of selenium in the blood helps to reduce the titer of antibodies to TSH receptors. The positive effect of reducing antibodies occurs with the normalization of inhibited low levels of TSH. High levels of $\mathrm{fT}_{4}, \mathrm{fT}_{3}$, increased thyroid volume and high levels of iodine increase the risk of antibodies to the thyroid-stimulating hormone receptor.

Keywords: Graves' disease, blood selenium, iodine excretion with urine, risk factors.

\author{
ЗАБЕЗПЕЧЕННЯ СЕЛЕНОМ ТА СТАН ЩИТОПОДІБНОЇ ЗАЛОЗИ \\ ПРИ ХВОРОБІ ГРЕЙВСА В ЕНДЕМІЧНОМУ \\ ЩОДО ЙОДНОГО ДЕФІЦИТУ РЕГІОНІ \\ Кравченко B. I. ${ }^{1}$, Grossman A. B. ${ }^{2}$, Раков O. В. ${ }^{1}$, \\ Ковзун О. I. ${ }^{1}$, Паньків В. I. ${ }^{3}$, Сімуров О. В. ${ }^{1}$ \\ ${ }^{1}$ ДУ «Інститут ендокринології та обміну речовин ім. В. П. Комісаренка НАМН Украӥни», \\ м. Київ, Україна; \\ ${ }^{2}$ Green-Templeton College at the University of Oxford, UK, Великобританія; \\ ${ }^{3}$ Український науково-практичний центр ендокринної хірургї̈, \\ трансплантації ендокринних органів і тканин МОЗ України, \\ м. Київ, Украӥна \\ endocr@i.ua
}

Метою дослідження було визначити рівень селену в сироватці крові, медіану йодурії, взаємозв'язок між рівнями селену та йодурії у пацієнтів із хворобою Грейвса. Обстежено 141 мешканцям Киева та Київської області, з них 37 без тиреоїдної патології (контрольна група віком $39,7 \pm 2,7$ років) та $104-$ із хворобою Грейвса (дослідна група, віком 43,25 $\pm 1,18$ роки). Рівень селену в сироватці крові хворих був достовірно зниженим порівняно з показником контрольної групи. Медіана вмісту селену в крові становила 29,35 [6,85-58,77] мкг/л. 3 віком хворих дефіцит селену посилювався. При дослідженні показників тиреоїдного статусу група паціентів із хворобою Грейвса відрізнялась від контрольної підвищеним рівнем тиреоїдних гормонів, зниженим рівнем ТТГ, збільшеним тиреоїдним об'ємом. Виявлено суттеве збільшення рівня антитіл до рецепторів ТТГ. Залежності цих показників від статі та віку хворих не спостерігалося. Медіана екскреції йоду з сечею в дослідній групі достовірно відрізнялась $(\mathrm{p}<0,05)$, їі показник в контрольній групі становив 78,9 мкг/л, що вказувало на наявність йодного дефіциту, в дослідній групі вона становила 177,05 мкг/л. Через 3, 6 місяців після прийому тіамазолу рівень селену в крові збільшився, але залишався нижчим порівняно з показниками контрольної групи. Також спостерігалась нормалізація рівнів тиреоїдних гормонів та ТТГ. В групі хворих зареестрований зв'язок між рівнем селену та йодурією $(\mathrm{p}<0,05)$, а також кореляція між титром антитіл до рецептора ТТГ та показниками функції щитоподібної залози $(\mathrm{p}<0,05)$. Розрахунок ризиків змін титру антитіл залежно від рівня селену та інших досліджених фокторів показав, що підвищення рівня селену в крові сприяе зниженню титру антитіл до рецепторів ТТГ. Позитивний ефект зменшення антитіл відбувається при нормалізації загальмованого низького рівня ТТГ. Високі рівні в $\mathrm{T}_{4}$, в $\mathrm{T}_{3}$, збільшений тиреоїдний об’ем та високий рівень йоду підвищують ризик виникнення антитіл до рецептора тиреотропного гормону.

К лючов і слов а: хвороба Грейвса, селен, екскреція йоду із сечею, чинники ризику. 